\title{
Legalitas UMKM: Kunci Sukses Pengembangan dan Sinergi Pemasaran UMKM
}

\section{Ika Suhartatnti Darmo, Naik Henokh Parmenas, \& Donant A. Iskandar}

Fakultas Bisnis dan Ilmu Komunikasi, Institut Teknologi dan Bisnis Kalbis, Jakarta

\begin{abstract}
Amid the Covid-19 pandemic, entrepreneurs are required to be able to survive and seize business opportunities - the accuracy and strategy needed by every entrepreneur to reduce the impact caused by the pandemic. The community service activities held focused on answering the problems experienced by PKM Partners of the Kalbis Institute of Technology and Business, namely: PKM Partners are MSMEs in East Belitung where MSMEs experience various problems such as product marketing, online sales strategies, access to capital, financial management, raw materials, as well as difficulties in conventionally distributing their business. MSMEs in East Belitung Regency has good potential to be developed. The Covid-19 outbreak poses a threat to MSMEs to develop their businesses. The PKM activities that will be held are focused on answering the problems experienced by PKM partners of the Kalbis Institute of Technology and Business.
\end{abstract}

Keywords

Legality, marketing synergy, micro, small $\mathcal{E}$ medium enterprises

BERDAYA : Jurnal Pendidikan dan Pengabdian Kepada Masyarakat Vol 3, No.2, Agustus 2021, pp. 85-94 eISSN 2721-6381

\section{Article History}

Received 02 Aug 2021 / Accepted 27 Aug 2021 / First Published: 31 Aug 2021

To cite this article

Darmo, I., Parmenas, N., \& Iskandar, D. (2021). Legalitas UMKM: Kunci Sukses Pengembangan dan Sinergi Pemasaran UMKM. BERDA YA: Jurnal Pendidikan Dan Pengabdian Kepada Masyarakat, 3(2), 85 - 94

DOI: $10.36407 /$ berdaya.v3i2.389

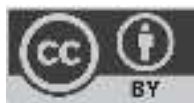

(C) The Author(s)2021

. This open access article is distributed under a Creative Commons Attribution (CC-BY) 4.0 license 
Di tengah pandemi Covid-19, wirausahawan dituntut untuk mampu bertahan dan menangkap peluang bisnis-ketepatan dan strategi yang dibutuhkan setiap wirausahawan untuk mengurangi dampak yang ditimbulkan oleh pandemi. Kegiatan pengabdian masyarakat yang diadakan difokuskan untuk menjawab permasalahan yang dialami oleh Mitra PKM Institut Teknologi dan Bisnis Kalbis yaitu: Mitra PKM adalah UMKM di Belitung Timur dimana UMKM mengalami berbagai permasalahan seperti pemasaran produk, strategi penjualan online, akses permodalan, pengelolaan keuangan, bahan baku, serta kesulitan dalam mendistribusikan usahanya secara konvensional. UMKM di Kabupaten Belitung Timur memiliki potensi yang baik untuk dikembangkan. Wabah Covid-19 menjadi ancaman bagi UMKM untuk mengembangkan usahanya. Kegiatan PKM yang akan diselenggarakan difokuskan untuk menjawab permasalahan yang dialami oleh mitra PKM Institut Teknologi dan Bisnis Kalbis..

Kata Kunci : Legalitas, sinergi pemasaran, UMKM
Ika Suhartanti Darmo

Naik Henokh Parmenas

Fakultas Bisnis dan Komunikasi

Program Studi Manajemen Kalbis Institute

\section{PENDAHULUAN}

UMKM memberikan kontribusi yang cukup besar bagi perekonomian yang tidak perlu diragukan lagi. UMKM memberikan kontribusi yang cukup besar terhadap PDB, yaitu sekitar $60.34 \%$ dan memberikan sumbangan besar bagi penyerapan tenaga kerja (umkm-id.com, 2018). Berbagai permasalahan menyebabkan UMKM sulit berkembang. Salah satunya adalah kendala dalam memilih strategi yang tepat. Tingkat literasi dan juga inklusi keuangan yang rendah juga mendorong rendahnya perkembangan UMKM ditambah terjadinya wabah pandemic Covid 19 yang membuat pergerakan UMKM semakin terbatas.

Terdapat permasalahan kapasitas bisnis yang dihadapi UMKM untuk berproduksi. UMKM sebagai lembaga perlu yakin menetapkan aktivitas utama (core) bisnis dalam berproduksi. Selain itu, penguatan kapasitas usaha dibutuhkan oleh UMKM meliputi kapasitas sumber daya manusia, pembiayaan/permodalan, dan pemetaan peluang pasar barang produksi. Dampak dari permasalahan yang dihadapi pelaku UMKM tersebut adalah produk yang tidak kompetitif dipasaran dan juga sepi peminatnya. Selain itu, persoalan klasik terkait dengan pembiayaan dan pengembangan usaha masih merupakan permasalahan yang belum dapat terpecahkan. Pada tahun 2014, dari 56.4 juta UMK di Indonesia, hanya 30\%-nya yang mampu mengakses pembiayaan. Dari persentase tersebut, sebanyak $76.1 \%$ memperoleh kredit bank dan $23.9 \%$ mengakses dari non bank yang termasuk dari usaha simpan pinjam seperti koperasi. Dengan kata lain, sekitar 60-70\% dari seluruh sector UMKM belum memiliki akses pembiayaan melalui perbankan (LPPI \& BI, 2015).

Ditetapkan pada Tahun 2003 sebagai daerah otonomi baru Kabupaten Belitung Timur memiliki luas darat $2.506,90 \mathrm{~km}^{2}$ dan luas wilayah laut $15.461,03 \mathrm{~km}^{2}$ dengan total luas keseluruhan wilayah mencapai 17.967,93 $\mathrm{km}^{2}$. Kabupaten Belitung Timur dibagi menjadi 7 (tujuh) Kecamatan yakni: Manggar, Gantung, Dendang, Kelapa Kampit, Damar, Simpang 
Renggiang, dan Simpang Pesak. Kecamatan Manggar menjadi ibukota Kabupaten Belitung Timur dengan jumlah penduduk terbanyak. Kondisi sosial masyarakat banyak bekerja disektor informal seperti pada area jasa, jasa konstruksi, karyawan, UMKM dan lainnya. Sektor informal tersebut melingkupi bidang kepariwisataan, perikanan, perkebunan, pembuatan kerupuk, usaha kuliner dan industri pengolahan lainnya

\section{Jenis Mitra}

Mitra dalam kegiatan PKM ini adalah kelompok pelaku UMKM yang berada di Kabupaten Belitung Timur. Kelompok ini merupakan bagian dari upaya pembangunan kesejahteraan masyarakat setempat. Melihat potensi yang dipetakan, Kabupaten Belitung Timur bergerak pada sektor lokal dan kemampuan masyarakat yang dimiliki. Wilayah yang saling terkoneksi menjadi suatu keuntungan dalam pergerakan barang jasa produksi yang dihasilkan dengan juga perlu memperkuat sektor pengolahan UMKM yang ditingkatkan kembali.

\section{Persoalan Mitra}

Berdasarkan hasil observasi dan wawancara awal dengan pihak mitra, pelaksana melihat bahwa pelaku UMKM memiliki beberapa kendala. Kendala pertama yang dihadapi adalah terkait strategi penjualan produk, kurangnya kemampuan beradaptasi dengan pemasaran secara digital hingga keengganan para pelaku UMKM mengubah gaya transaksi mereka, kesulitan dalam mendistribusikan produk, pengelolaan keuangan, dan akses permodalan. Di tengah pandemi Covid-19, pelaku UMKM setempat merasa kesulitan dengan akses permodalan dan bahan baku produksi. Lebih lanjut selama pandemic Covid 19, beberapa pelaku UMKM mengubah skema pembelian bahkan menghentikan proses produksi akibat sulitnya mendapatkan bahan baku di tengah pandemi. Tidak hanya modal dan bahan baku, pelaku UMKM juga merasa kesulitan dalam melakukan distribusi atas produk yang mereka produksi. Sejumlah pelaku UMKM menggandeng pihak lain dalam melakukan distribusi terhadap produknya, seperti kantin sekolah, toko dll. Dengan demikian, saat pandemi Covid19 terjadi, pelaku usaha harus mencari alternatif lain dalam mendistribusikan produknya.

\section{Sarana Komunikasi Mitra}

Mitra tersebar di beberapa Kecamatan Belitung Timur. Akses komunikasi dengan mitra dilakukan melalui telepon serta aplikasi pesan instan dikoordinasi dengan organisasi Ikatan Keluarga Alumni Perguruan Tinggi Kepamongprajaan Belitung Timur (IKAPTK Beltim) dan dibantu oleh Wakil Bupati Belitung Timur. Koneksi internet setempat yang memadai memudahkan pelaksana untuk berkoordinasi guna melakukan sinkronisasi kebutuhan mitra dengan ketersediaan materi yang dimiliki pelaksana.

\section{Permasalahan Mitra}

Berdasarkan komunikasi terakhir yang telah dilakukan melalui observasi dan wawancara awal, diperoleh informasi-informasi khusus terkait permasalahan yang dialami oleh mitra PKM sebagai berikut:

1. Potensi UMKM di Kabupaten Belitung Timur cukup baik untuk dikembangkan;

2. Wabah Covid-19 memberikan peluang dan ancaman bagi UMKM untuk mengembangkan usahanya;

3. Mitra PKM adalah UMKM di Belitung Timur di mana UMKM mengalami berbagai permasalahan seperti pemasaran produk, strategi penjualan secara online, pengelolaan keuangan, akses permodalan, bahan baku, dan juga kesulitan dalam mendistribusikan usahanya secara konvensional. 


\section{Solusi yang Ditawarkan}

Solusi yang ditawarkan berdasarkan dari permasalahan yang sudah dipaparkan sebelumnya adalah mencoba untuk membantu dari sisi akademisi, serta pendampingan, antara lain:

1. Knowledge sharing

2. Pemberian Motivasi

3. Workshop

\section{Sasaran Kegiatan}

Jumlah mitra PKM yang berada di Kabupaten Belitung Timur berjumlah 16 pelaku UMKM yang tersebar di Kabupaten Belitung Timur. Mitra PKM adalah pria dan wanita yang bekerja sebagai pelaku usaha mikro kecil dan menengah di Kabupaten Belitung Timur.

\section{Manfaat Kegiatan}

Setelah pelatihan dilaksanakan diharapkan dapat memberi manfaat:

1. Mitra UMKM memiliki pengetahuan strategi model bisnis canvas.

2. Mitra UMKM termotivasi untuk tetap focus ditengah keterbatasan saat pandemi

3. Mitra UMKM memiliki pengetahuan tentang pengelolaan keuangan secara sederhan

4. Mitra UMKM termotivasi untuk rutin membuat catatan keuangan.

5. Para pelaku UMKM termotivasi untuk meningkatkan peranannya dalam meningkatkan kinerja UMKM-nya

Selain manfaat dalam segi mitra PKM, dalam segi akademik diharapkan hasil dari PKM ini dapat dipublikasikan sebagai karya ilmiah yang dapat dibagikan kepada masyarakat melalui jurnal-jurnal Abdimas.

\section{MATERI DAN METODE}

\section{Lokasi Mitra}

Kabupaten Belitung Timur merupakan daerah otonomi baru dengan luas darat $2.506,90 \mathrm{~km}^{2}$ dan luas wilayah laut $15.461,03 \mathrm{~km}^{2}$ dengan total luas keseluruhan wilayah mencapai 17.967,93 km². Kabupaten Belitung Timur dibagi menjadi 7 (tujuh) Kecamatan yakni: Manggar, Gantung, Dendang, Kelapa Kampit, Damar, Simpang Renggiang, dan Simpang Pesak. Kecamatan Manggar menjadi ibukota Kabupaten Belitung Timur dengan jumlah penduduk terbanyak. Kondisi sosial masyarakat banyak bekerja disektor informal seperti pada area jasa, jasa konstruksi, karyawan, UMKM dan lainnya. Sektor informal tersebut melingkupi bidang kepariwisataan, perikanan, perkebunan, pembuatan kerupuk, usaha kuliner dan industri pengolahan lainnya

Adapun lokasi mitra dengan Institusi Kalbis berjarak sekitar 1330 km. Sebagai pusat kota, Kantor Bupati dan Wakil Bupati berkedudukan di Kecamatan Manggar. Lebih lanjut, Kecamatan Manggar berbatasan langsung dengan beberapa daerah lainnya di Belitung Timur. Di bagian utara, Kecamatan Manggar berbatasan dengan Kecamatan Kelapa Kampit dan Damar; di selatan berbatasan dengan Laut Jawa; di barat berbatasan dengan Kecamatan Simpang Renggiang dan Gantung; serta di timur berbatasan dengan Selat Karimata. 


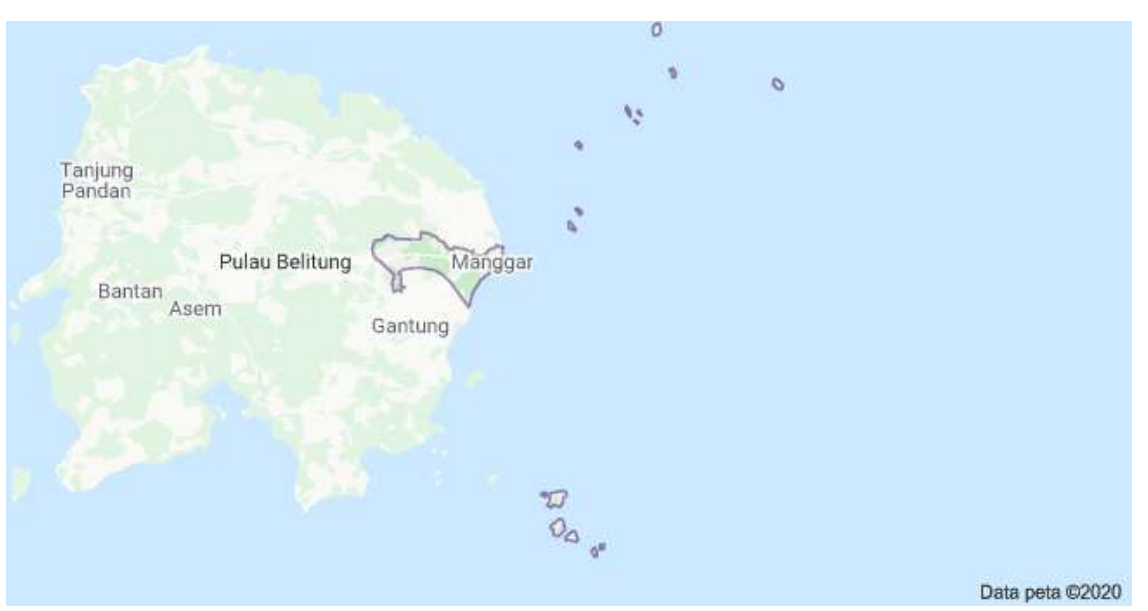

Gambar 1.

Lokasi Mitra Kecamatan Manggar, Kabupaten Belitung Timur

Sumber: Google Maps, 2021

Dalam kegiatan PKM yang dilakukan, metode pelatihan disampaikan berupa presentasi mengenai topik materi serta diskusi tanya jawab seputar topik yang diberikan. Serta kelompok peserta para pelaku UMKM di Belitung Timur juga diberikan kesempatan untuk sharing pengalaman terkait topik dari pemateri.

Adapun materi yang disampaikan antara lain:

\section{Knowledge sharing}

Knowledge sharing dalam bentuk diskusi tentang strategi pengembangan UMKM menggunakan business model canvas dan bagaimana mengelola keuangan UMKM secara sederhana. Weygandt et al (2011: 45) Kas merupakan alat pertukaran yang dimiliki dan siap digunakan di dalam transaksi setiap saat diinginkan. Weygandt et al (2011: 46) juga menyatakan arus kas adalah suatu laporan tentang aktivitas penerimaan dan pengeluaran kas di dalam suatu periode tertentu, beserta penjelasan tentang sumber-sumber penerimaan dan pengeluaran kas tersebut. Dengan memberikan pemahaman serta sharing pengalaman tentang pengelolaan keuangan UMKM secara sederhana terutama terkait kas, diharapkan peserta dapat tambahan wawasan terkait tips-tips bagaimana mengelola keuangan.

\section{Pemberian Motivasi}

Motivasi adalah pendorong untuk melakukan sesuatu, motivasi bisa untuk hal yang baik maupun yang buruk atau negatif dan positif. Menurut Winardi (2002:1) mengemukakan bahwa motivasi (motivation) berasal dari perkataan latin yakni movere yang berarti menggerakan (to move). Motivasi adalah pemberian daya penggerak yang menciptakan kegairahan kerja seseorang agar mereka mau bekerja dengan segala daya upayanya untuk mencapai kepuasan (Hasibuan, 2007: 95). Dalam kegiatan ini, tim PKM akan memberikan dorongan semangat positif yang diawali dengan menyamakan pandangan mereka bahwa, dengan memotivasi agar setiap pelaku UMKM mencoba strategi berdasar pemahaman yang telah diberikan. Selain itu, pelaku UMKM mampu membuat pengelolaan keuangan secara sederhana minimal memiliki atau rutin membuat catatan pemasukan dan pengeluaran kas guna membantu memonitoring aktivitas keuangan usaha.

\section{Workshop}

Workshop dalam bentuk pelatihan secara sederhana bagaimana contoh praktik membuat model bisnis canvas dan membuat catatan keuangan sederhana. 


\section{PELAKSANAAN KEGIATAN DAN EVALUASI}

\section{Kondisi Awal Mitra}

Berdasar data yang diperoleh, jumlah penduduk usia 20-59 tahun sebanyak 69.556 penduduk, dimana jumlah ini merupakan penduduk dengan usia produktif. Kondisi demografi ini menjadi salah satu keuntungan bagi kabupaten Belitung Timur untuk menggerakkan masyarakat dalam keikutsertaannya pada pembangunan daerah. Keikutsertaan tersebut tentunya melibatkan kelompok usia masyarakat dalam berbagai program yang dibangunan dan disajikan guna peningkatan kesejahteraan masyarakat. Pembangunan menyasar pada manusia itu sendiri menjadi strategi yang sering digunakan untuk meningkatkan taraf hidup masyarakat. Hal tersebut menghasilkan berbagai program/kegiatan Pemerintah Daerah guna menciptakan kesejahteraan melalui tugasnya dengan mengatur masyarakat, memberdayakan masyarakat dan melayaninya. Berdasarkan hasil observasi yang dilakukan pelaksana, dapat ditemukan bahwa mitra merupakan pelaku UMKM yang berada di Kabupaten Belitung Timur. Kebanyakan pelaku UMKM yang menjadi mitra bergerak pada bidang perdagangan, kepariwisataan, produksi pengolahan ikan, kerupuk, kopi, makanan ringan serta kuliner. Pemasaran produk UMKM yang belum terkoordinasi dan perlu kerja seutuhnya agar hasil produksi masyarakat dapat diserap oleh pasar. Selain itu juga investor masih jarang melirik dan bersinergi dengan Pemerintah Kabupaten dalam mendorong pembangunan dan aktivitas ekonomi.

\section{Pendidikan Mitra}

Latar Belakang Pendidikan yang menjadi Mitra PKM adalah pria dan wanita yang merupakan lulusan Sekolah Menengah Pertama (SMP/MTs) dan Sekolah Menengah Atas (SMA/SMK).

\section{Pelaksanaan Kegiatan}

Kegiatan pemberian materinya dilaksanakan dalam 1 (satu) kali pertemuan secara online melalui media aplikasi zoom yakni pada Kamis tanggal 11 Februari 2021 dari jam 08.00 WIB sampai dengan jam 17.00 WIB. Adapun susunan acara pada saat kegiatan PKM dilaksanakan, adalah sebagai berikut:

Susunan Acara Kegiatan 1 Knowledge sharing tentang strategi business canvas model

$08.00-08.30 \quad$ Persiapan pemateri, registrasi peserta

08.30 - $09.00 \quad$ Pembukaan oleh Kepala PKM Kalbis Institut

$09.00-09.15 \quad$ Kata sambutan oleh Deputi Wakil Rektor 1 Kalbis Institur

09.15 - $09.30 \quad$ Kata sambutan dari Wakil Bupati Belitung Timur

09.30 - $11.30 \quad$ Sesi I : Knowledge sharing tentang Business Model Canvas

$11.30-12.00 \quad$ Tanya jawab sesi 1

$12.00-13.00 \quad$ Ishoma

Susunan Acara Kegiatan 2 Motivasi tentang pentingnya strategi UMKM di masa pandemi dan mengelola keuangan secara sederhana.

$13.00-14.00 \quad$ Sesi 2: Diskusi tentang pentingnya strategi UMKM di masa pandemi dan mengelola keuangan secara sederhana

$14.00-14.30 \quad$ Tanya jawab sesi 2

$14.30-15.00 \quad$ Break Sholat Ashar

Susunan Acara Kegiatan 3 Workshop mengelola keuangan secara sederhana

$15.00-16.30 \quad$ Sesi 3: Workshop mengelola keuangan secara sederhana 
Ika Suhartanti Darmo et al.

Legality, marketing synergy, micro, small \& medium enterprises

$\begin{array}{ll}16.30-17.00 & \text { Tanya jawab sesi } 3 \\ 17.00-17.30 & \text { Penutupan acara, administrasi dan dokumentasi }\end{array}$

Adapun rincian kegiatan terinci sebagai berikut:

Tabel 1.

Rincian Kegiatan

\begin{tabular}{|c|c|c|c|}
\hline Hari/Tanggal & Pelaksanaan & Kegiatan & $\begin{array}{c}\text { Jumlah } \\
\text { Jam }\end{array}$ \\
\hline 5 Januari 2021 & $09.00-12.00$ & $\begin{array}{l}\text { Rapat Persiapan I (Persiapan pelaksanaan, } \\
\text { observasi, PIC) }\end{array}$ & 3 \\
\hline \multirow[t]{2}{*}{7 Januari 2021} & $08.00-11.00$ & $\begin{array}{l}\text { Observasi dengan teleconference melalui } \\
\text { zoom dengan Camat Manggar Belitung } \\
\text { Timur yakni Bapak Amirudin }\end{array}$ & 3 \\
\hline & $11.00-14.00$ & $\begin{array}{l}\text { Observasi dengan teleconference melalui } \\
\text { zoom dengan Pelaku UMKM Belitung Timur } \\
\text { Bapak Hasbullah dan Bapak Tatan (Ikatan } \\
\text { Alumni Perguruan Tinggi Kepamongprajaan } \\
\text { (IKAPTK) Belitung Timur }\end{array}$ & 3 \\
\hline 8 Januari 2021 & $09.00-12.00$ & $\begin{array}{l}\text { Rapat Persiapan } 2 \text { (Pembentukkan tim PKM, } \\
\text { pembagian job desk) }\end{array}$ & 3 \\
\hline $\begin{array}{l}\text { 11 Januari } \\
2021\end{array}$ & $08.00-17.00$ & Pembuatan Proposal & 9 \\
\hline $\begin{array}{l}29 \text { Januari } \\
2021\end{array}$ & & Proposal disetujui & \\
\hline $\begin{array}{l}3 \text { Februari } \\
2021\end{array}$ & $13.30-16.30$ & Rapat Persiapan 3 (Rapat Materi PKM) & 3 \\
\hline $\begin{array}{l}5 \text { Februari } \\
2021\end{array}$ & $08.00-17.00$ & Pembuatan materi & 9 \\
\hline $\begin{array}{l}8 \text { Februari } \\
2021\end{array}$ & $09.00-12.00$ & $\begin{array}{l}\text { Rapat persiapan } 4 \text { (cek materi, persiapan di } \\
\text { lapangan) }\end{array}$ & 3 \\
\hline \multirow[t]{4}{*}{$\begin{array}{l}11 \text { Februari } \\
2021\end{array}$} & $07.00-07.30$ & $\begin{array}{l}\text { Koordinasi dengan mitra terkait koneksi } \\
\text { internet, jumlah peserta, dan sebagainya }\end{array}$ & 0.5 \\
\hline & $07.30-09.00$ & Persiapan alat, registrasi dan kata sambutan & 1.5 \\
\hline & $09.00-17.00$ & Pelaksanaan Kegiatan & 8 \\
\hline & $17.00-17.30$ & Evaluasi Kegiatan & 0.5 \\
\hline \multirow[t]{2}{*}{$\begin{array}{l}20 \text { Februari } \\
2021\end{array}$} & $08.00-17.00$ & Pembuatan Laporan Akhir & 9 \\
\hline & & Total Jam & 55.5 \\
\hline
\end{tabular}

Sumber: Diolah Tim Pelaksana (2021) 


\section{Evaluasi Kegiatan}

Setelah proses pelaksanaan kegiatan, maka diadakan evaluasi untuk melihat apakah pelaksanaan pengabdian kepada masyarakat yang diberikan memiliki indikator keberhasilan. Evaluasi yang dilakukan adalah dengan menerima feedback dari pihak yang menjadi mitra kami.

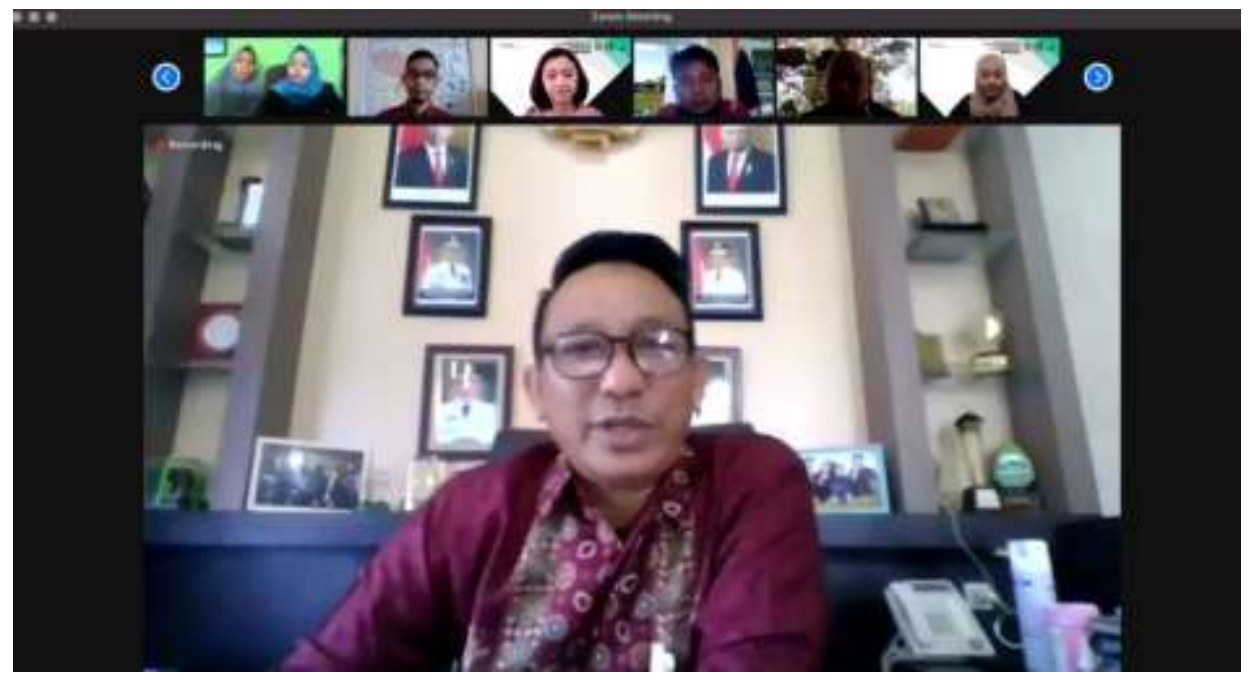

Gambar 2.

Pembukaan acara

Sumber: dokumentasi tim pelaksana

\section{Indikator Keberhasilan}

Ukuran indikator keberhasilan suatu pelatihan bisa dilihat dari antusias mitra aktif dalam mengikuti pelatihan serta feedback dari mitra PKM. Pelatihan ini melihat perubahan setelah mereka mendapatkan pelatihan dan juga proses monitoring setelah proses pelatihan ini berjalan. Terlihat antusiasme mitra UMKM dalam menyimak, memahami materi pelatihan, dan tanya jawab.

\section{Keberlanjutan Kegiatan di Mitra}

Proses pelaksanaan PKM diharapkan dapat berlanjut lagi dengan terus memonitor kegiatan yang sudah berjalan, dengan selalu didukung oleh motivasi, dan pelatihan untuk pemahaman dan peningkatan kualitas keterampilan pelaku UMKM di Belitung Timur sehingga mampu mendukung kesejahteraan peserta pada khususnya dan masyarakat sekitar pada umumnya.

\section{Peran Serta Mitra dalam Kegiatan (Keaktifan)}

Peran serta mitra dalam kegiatan ini adalah berkontribusi dalam pelaksanaan kegiatan pengabdian kepada masyarakat sebagai peserta. Mitra sangat antusias dan terbuka terkait topik-topik yang diberikan oleh tim PKM Kalbis Institute. Mitra-pun berharap kegiatan seperti ini berkelanjutan sehingga mitra tidak hanya mendapat materi teori saja tertapi belajar pada prakteknya dan dapat mendiskusikan masalah-masalah dan hambatan yang dihadapi. Masih banyak topik-topik yang dapat diberikan ke mitra sesuai permasalahan yang dihadapi oleh mitra. Mitra juga mengharapkan adanya program pendampingan untuk kegiatan berikutnya.

\section{Peranan/Tugas Mitra dalam Kegiatan}

Peranan dan tugas mitra dalam kegiatan PKM adalah sebagai peserta didik PKM yang menerima materi pelatihan. Serta membantu koordinasi kesesuaian pelaksanaan kegiatan dan pengumpulan peserta. 
Ika Suhartanti Darmo et al.

Legality, marketing synergy, micro, small \& medium enterprises

\section{Produk/Kegiatan yang Dinilai Bermanfaat}

Berdasarkan hasil diskusi bersama mitra PKM, kegiatan yang dinilai sangat bermanfaat bagi mereka dari pelatihan yang diberikan, antara lain:

1. Strategi model bisnis canvas merupakan hal yang baru bagi peserta sehingga mereka tertarik untuk mencoba meskipun terkendala seperti akses pemasaran melalui internet, dan sebagainya

2. Bagaimana mengelola keuangan secara sederhana dan mudah

3. Memberikan wawasan mengenai strategi UMKM di masa pandemi.

Kegiatan pengabdian kepada masyarakat yang diselenggarakan difokuskan untuk menjawab permasalahan yang dialami oleh Mitra PKM Institut Teknologi dan Bisnis Kalbis yakni:

1. Mitra PKM adalah UMKM di Belitung Timur di mana UMKM mengalami berbagai permasalahan seperti pemasaran produk, strategi penjualan secara online, akses permodalan, pengelolaan keuangan, bahan baku, dan juga kesulitan dalam mendistribusikan usahanya secara konvensional.

2. UMKM di Kabupaten Belitung Timur memiliki potensi yang cukup baik untuk dikembangkan.

3. Wabah Covid-19 memberikan ancaman bagi UMKM untuk mengembangkan usahanya.

Kegiatan PKM yang akan diselenggarakan difokuskan untuk menjawab permasalahan yang dialami oleh mitra PKM Institut Teknologi dan Bisnis Kalbis.

\section{SIMPULAN}

Pelaksanaan kegiatan PKM berjalan lancar, manfaat yang diperoleh oleh mitra yakni pelaku UMKM di Belitung Timur setelah mengikuti pelatihan adalah:

1. Menambah pengetahuan mitra tentang bagaimana strategi model bisnis canvas.

2. Membuat perencanaan hingga control keuangan diperlukan oleh setiap pelaku usaha. Para pelaku usaha dapat mengontrol aktivitas keuangan dengan membuat pencatatan secara sederhana.

3. Kerjasama berkelanjutan dengan mitra PKM yang dalam hal ini adalah pelaku UMKM di Belitung Timur.

Adapun berdasar kegiatan yang telah dilakukan, saran untuk kegiatan PKM selanjutnya dapat diberikan pelatihan mengenai:

1. Workshop membuat logo dan merk

2. Workshop membuat kemasan yang menarik

3. Webinar terkait Hak Kekayaan intellectual (HAKI)

4. Membuat anggaran/budgeting untuk persiapan menghadapi kondisi kritis

5. Workshop ide bisnis.

6. Praktik pemasaran melalui media sosial

\section{REFERENSI}

LPPI \& BI. (2015). Profil Bisnis Usaha Mikro, Kecil dan Menengah. LPPI \& BI. umkm-id.com. (2018).

Kontribusi UMKM Dalam Roda Perekonomian Indonesia. Retrieved from umkm-id.com: https:/ / umkm-id.com/post/ kontribusi-umkm-dalam-roda-perekonomian-indonesia Pakpahan, R., dan Fitriani, Y. (2020). Analisa Pemanfaatan Teknologi Informasi Dalam 
Pembelajaran Jarak Jauh Di Tengah Pandemi Virus Corona Covid-19. JISAMAR (Journal of Information System, Applied, Management, Accounting and Research). Retrieved from http://journal.stmikjayakarta.ac.id/index.php/jisamar/issue/view/20

Taufik dan Ayuningtyas, E.A. (2020). Dampak Pandemi Covid 19 Terhadap Bisnis Dan

Eksistensi Platform Online. Jurnal Pengembangan Wiraswasta. Vol. 22 No. 01. STIE IPWIJA. Jakarta.

Weygandt, J. J., Kimmel, P. D., and Kieso, D. E. (2011). Accounting Principle. Tenth Edition. John Wiley \& Sons, Inc. USA.

\section{About the Author}

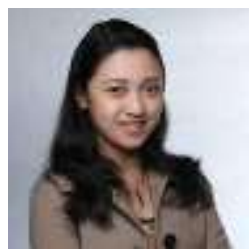

Ika Suhartanti Darmo, Dosen Manajemen dan Kewirausahaan Kalbis Institute, Doktor lulusan Universitas Pendidikan Indonesia Bandung

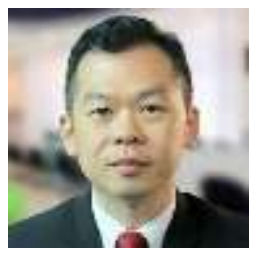

Naik Henokh Parmenas, Rektor Kalbis Institute, Dosen Aspek Hukum Dalam Bisnis

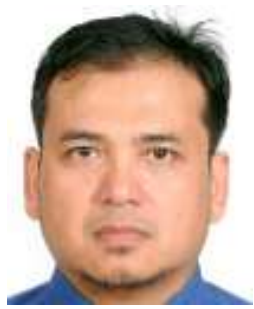

Donant Alananto Iskandar, Dosen Manajemen Kalbis Institute

\section{Declarations}

\section{Funding}

Kegiatan ini merupakan bagian dari program Pengabdian Kepada Masyarakat yang didanai oleh Fakultas Bisnis dan Komunikasi Kalbis Institute tahun 2021

\section{Competing Interests}

Tidak ada konflik kepentingan untuk diungkapkan. 